\title{
補強土防護擁壁の急傾斜における 実物大性能試験
}

\author{
吉田眞輝 1 - 竜田尚希 $2 \cdot$ 西田陽 $-3 \cdot$ 井上昭一 4 -八嶋厚 $5 \cdot$ 沢田和秀 6 - 森口周二 7
}

\begin{abstract}
近年、土とジオテキスタイルを使用した補強土による「補強土防護擁壁工」が落石対策を主に実績が増えて きている。この工法は土の柔軟性による衝撃緩和効果と補強土の耐力（強さ）を併せ持ち,広範囲のエネルギー （100 5000KJ以上）に対応できるとともに、現地発生土や流用土を使用することでコスト削減にも努める工 法である。過去、落石に対する実用性の試験を数回実施 ${ }^{12}{ }^{2}$ しているが、今回の実験では急傾斜地における土 砂崩壊を想定して、実物大モデルに石及び土砂を衝突させて補強土防護擁壁の耐久性を確認した。実験では2 つのタイプによる防護壁を構築した。本編では実験モデルの構造・施工方法および計測結果について報告する。
\end{abstract}

キーワード：土砂崩壊、落石、補強土擁壁、拘束効果、土砂災害防止法

\section{1. 実験の背景}

補強土防護擁壁はその性能も数多くの実験から実証さ れて施工実績も徐々に増加し始めている。特に落石に関 しては現在50件以上の実績数であり,これからも実績は 伸びてゆくものと思われる。これは, 従来工法に比較し て施工が容易なことと，衝撃力に対した施工コストが低 いことなどが奇与していると考えられる。特に重量構造 物でありながらの, 衝撃吸収性能は他に追従するものが なく外観の安心感とそれに伴う性能で信頼が得られてい る。

そのような中, 補強士防護擁壁は急傾斜における小規 模落石もしくは堆積土砂のポケットとしても施工されて きている。これらの対策は従来コンクリート擁壁とフェ ンスといった組み合わせがほとんどであり, 現況設計に おける小規模落石や堆積土砂のポケットとしてコスト・ 性能共に十分な役割を果たしていた。しかし近年土砂災 害防止法が勧告され, 設計時に上述の条件に加え, 崩落土 砂衝撃力を見込むとされた3)。この土砂崩壊力は斜面状 態にもよるが,算出すると通常数10kN〜100kNレベルとな り構造物の重量のみで力に抵抗するコンクリート擁壁は, 重量増加のためコンクリート量が増え不経済となる。そ こで補強土防護擁壁のもつ衝撃吸収性能により土砂衝撃 力に対する構造断面の縮小化・コス卜縮减を図れないか と考えた。
補強土防護擁壁は台形状であり構造物側面にて衝撃を 受け止める構造であるため, 斜面下部に若干の平場があ ることと斜面勾配が比較的緩いところであることが設置 条件となる。しかし実際の急傾斜地は急峻で狭いところ が多く,切土で設置スペースを作り構造物を構築してゆ くことが通常であり,側面受けの補強土防護擁壁では設 置不可能となる場合がある。そこで本実験では側面受け の従来の形状（以後ダイク型）に加え,補強土防護擁壁 天端で衝撃を受け止める形状（以後QK型）の2パターン により実物大モデルを構築し形状の違う石や土砂を衝突 させその挙動を確認する事とした。

\section{2. 実験概要}

（1）構造物の形状

今回の実験では, 図-1・2に示す側面で衝撃を受け 止めるダイク型と天端で受け止めるQK型の 2 タイプを 構築した。この 2 タイプは設置条件における形状のすみ 分けのために選択したもので、各タイプは以下のような 特徵を有する。

\section{a)ダイク型}

台形状に構築した衝撃力を側面で受けるタイプであり、 構築時に広めのスペースを必要とするが、地ならし程度 での直接基礎への設置が可能で本体工以外の工種がほと

\footnotetext{
1）正会員，前田工繊株式会社 技術部（T919-0422福井県坂井郡春江町沖布目）

2）前田工繊株式会社 営業推進部 主任（广919-0422福井県坂井郡春江町沖布目）

3）株式会社プロテックエンジニアリング 技術開発部長代理（テ950-0971新潟県新潟市近江155番地アクシス近汀2F）

4）株式会社プロテックエンジニアリング 取締役専務（テ950-0971新潟県新潟市近江155番地アクシス近江2F）

5）岐皁大学工学部社会基盤工学科 教授 (广501-1193岐皁県岐皁市柳戸1-1)

6) 岐皁大学工学部社会基盤工学科 助教授（广501-1193岐阜県岐皁市柳戸1-1)

7) 岐皋大学工学部社会基盤工学科 学術研究補佐員（广501-1193岐皁県岐皋市柳戸1-1)
} 
んどない。そのため施工が容易で経済的である。

b) QK型

切り立った斜面や設置スペースが少ない場所に補強土を 急勾配で立ち上げて確保した天端で衝撃力を受け止める タイプである。切土による構築場所の確保を行なう場合 が多いが、発生土を転用することにより材料費や運搬費 を削減することができる。

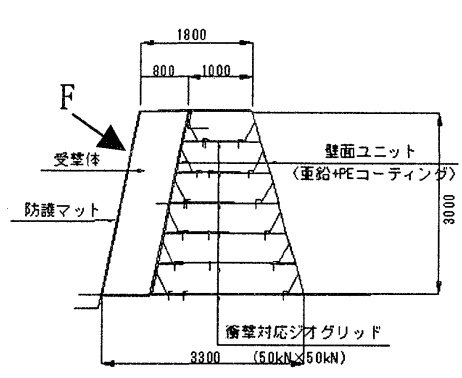

図-1. ダイク型形状

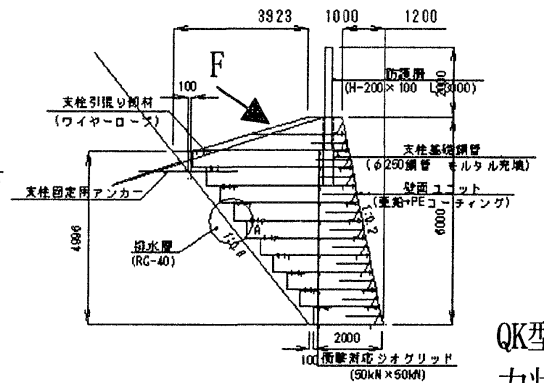

図-2. QK 型形状
（2）各構造物の衝撃吸収機構

両タイプとも盛土材に層状敷設したジオグリッドの拘束 効果により、強くて柔軟性を持った構造物となっている が 衝撃力の受け方の違いによりその構造が異なる。

a)ダイク型 :

落石や土砂を直接受け止めて衝撃力を分散する受撃体と、 分散された力を受け止める抵抗体で構成される。受撃体 は、高伸度繊維で製作した大型土のうの中に単粒度砕石 を充填してサンドバッグ状にしたものである。単粒度砕 石を中詰め材とするのは、締め固まらない材料を使用す ることで吸収層としての柔軟性を保つためである。抵抗 体は、500mm 毎に衝撃対応ジオグリッドを敷設した補強 土であり、ジオグリッドにより拘束された盛土材が、柔 軟な受撃体により分散された力に対して抵抗する。そ の衝撃吸収機構を図-3に示す
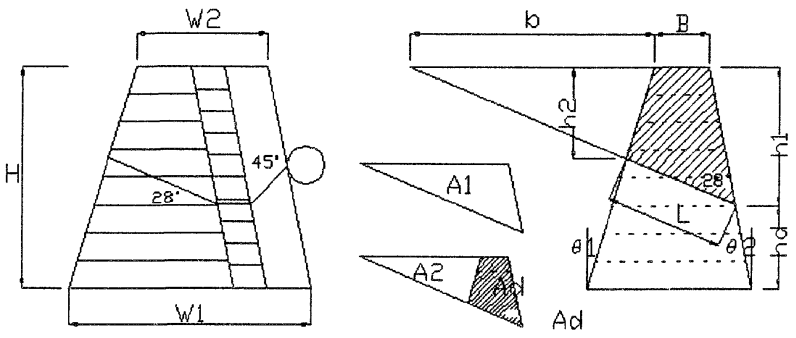

図ー3.ダイク型の衝撃吸収機構

図-3に示すメカニズムは過去の実験, 2)により得られ た解析結果であり, ダイク型前面に設置された受撃体 の変形により構造物鈆值方向に衝撃力を分散し, 低減 された力を補強土の抵抗力で受け止めるものである。

\section{b) QK型}

衝撃対応ジオグリッドを $500 \mathrm{~mm}$ 毎に敷設し、背面側を 巻き上げて盛土材を包み込む。盛土材を巻き込んだジオ グリッドが一種の袋体となり、衝撃力（袋体には压縮力 として作用）作用時に発生する土粒子の側方流動を拘
束・抑制する4)。この効果により盛土の耐力を増強する とともに、少ない設置幅での構築が可能となる。構造の 詳細を図-4に明示する。天端部には土砂や石のこぼれ 出し防止に防護柵を設置する。基礎は土中埋め込みとな るが、石などが衝突したときの倒れ防止用として地山に 定着したアンカーと支柱を連結する。

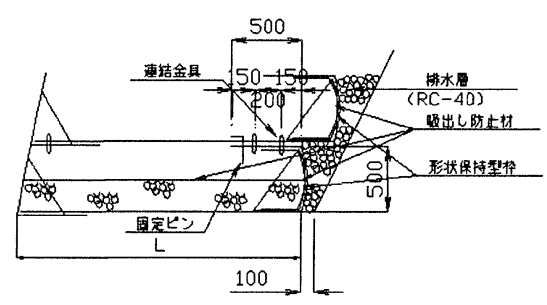

図一 4.QK 型構造詳細図

QK型の抵抗力は式（1）により算出する。そのときの応 力状態を図-5. 6に示す。

$$
\sigma 1+\frac{2 T}{B}=K p\left(\sigma 3+\frac{2 T}{h 0}\right) \cdots
$$

\section{ここに $\sigma 1,3:$ 主応力 $\left(\mathrm{kN} / \mathrm{m}^{2}\right)$}

$$
\begin{aligned}
& \mathrm{T} \text { :「土のう」に生じる応力 }(\mathrm{kN} / \mathrm{m}) \\
& \text { B:「土のう」の幅 (m) }
\end{aligned}
$$

Kp:受動土圧俰数 $(1+\sin \theta) /(1-\sin \theta)$ h0:一段当りの高さ (m)

※土のうの張力Tを拘束力に置き換える

$\sigma_{01}=2 \mathrm{~T} / \mathrm{B} \quad \sigma_{03}=2 \mathrm{~T} / \mathrm{h} 0$

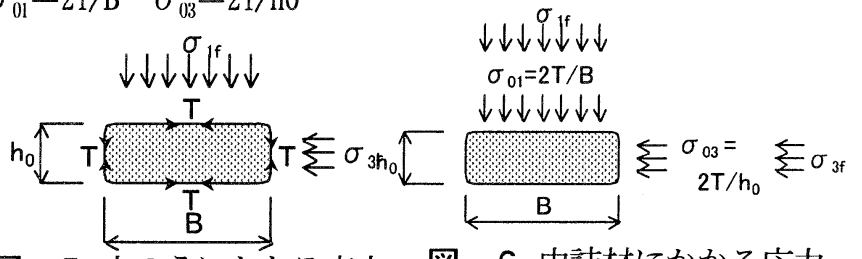

図一5.土のうにかかる応力 図一6.中詰材にかかる応力

\section{3 . 計測}

(1) 計測概要

QK型およびダイク型の計測器の配置概要を図-7.8に, 表-1 示す。衝撃対応ジオグリッドにひずみゲージを貼 り付け、士砂と落石の衝突時の挙動を確認した。構造物 の底盤部には土圧計を設置し地盤反力の変化を計測した。 壁面にはターゲットを貼付け、光波測距儀により壁面変 位を計測した。また、落石や土砂の落下挙動を高速度ビ デオカメラにより撮影した。

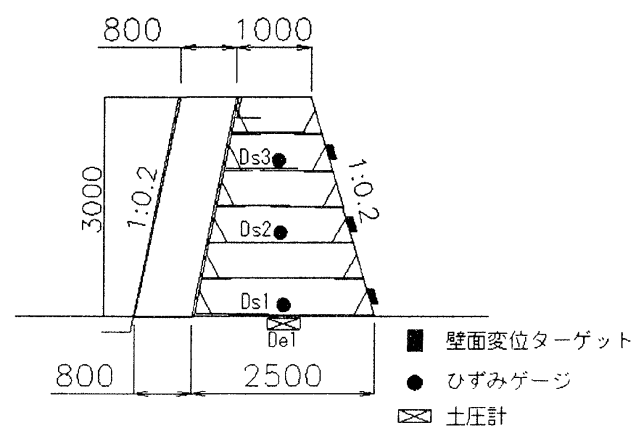

図ー7.ダイク型計測位置 


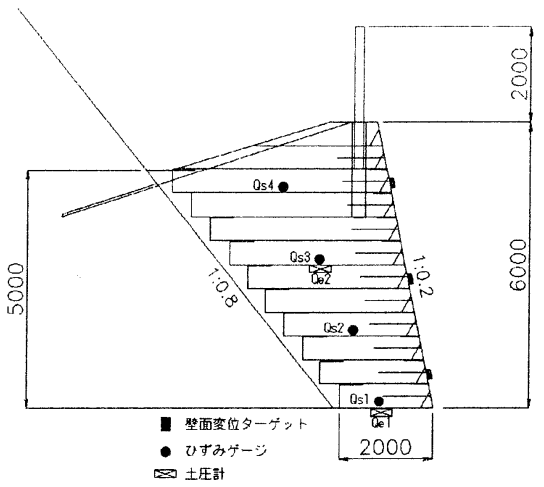

図-8.QK 型計測位置

表 -1 . 使用計測器一覧表

\begin{tabular}{|l|c|}
\hline \multicolumn{1}{|c|}{ 機器名称 } & 規格・容量 \\
\hline ひずみゲージ & KFG-2N-120-C1-11 L1M2R \\
\hline 土圧計 & KDA-200KAPA \\
\hline 壁面ターゲット & 平面反射板 \\
\hline 光波側距儀 & R-206c \\
\hline 高速度カメラ & SCH1-4 \\
\hline データロガ (動的) & DR+3 \\
\hline データロガ（静的） & UCAM-70A \\
\hline デジタルカメラ・ビデオ & \\
\hline 動的アンプ & MA-201ST \\
\hline
\end{tabular}

（2）計測機設置手順

・嵩上げ盛土構築後, 所定の位置に土圧計を置く。

・盛土構築, QK 型は 3 段（1500mm）毎に,ダイク型は 2 段

（1000mm）毎にひずみゲージつきジオグリッドを設置 する。

・構築完了後すべての計測機器の初期値を計測する。

·試験時, 外部機器の設置（データロガ・高速度カメ ラ・光波測距儀)。

・試験時の計測。衝撃力載荷後はすべての計測器の変位 （静的）を計測する。

\section{（3）計測の目的}

上記の計測器を使用して以下の項目を計測してその挙動 により効果の判定を行なう。

a) 土砂衝撃力

土砂の移動量および落下速度から土砂衝撃力を推定す るため,高速度カメラによる撮影を行い解析を行なう。

b) 補強土内の応力分布

補強土防護擁壁工法は衝撃力発生時にジオグリッド張 力により盛土材が拘束され, 粒子を安定させる手法であ る。そのため, ジオグリッドに発生する張力を確認する ことで応力分布幅が確認できると考え, ジオグリッドに ひずみゲージを取り付けその発生張力を各層每に計測す ることで応力の分布を確認した。

c) 底盤反力

コンクリート擁壁のような堅壁は, 構造物自体の衝撃 吸収能力が小さいので, 衝撃力載荷時の地盤反力は, 構造 物自重十衝撃力十 $\alpha$ と大きなものになる。

それに対し,補強土のような柔構造物では堤体内部で衝
撃を吸収する能力があるため衝撃力は底盤まで伝わりに くいと考えられる。

衝撃力載荷時の底盤反力を確認するため, 支持地盤境に 土圧計を設置した。

d）壁面変位

衝撃力は補強土の変形特性により吸収するため, 衝撃載 荷時は構造物にいくらかの変形が生じる。その変形量を 光波計測による座標変位で計測した。

\section{e) 挙動解析}

ひずみゲージおよび土圧計の反応を,データロガにより デー夕収集し解析を行なう。

（4）計測ケース

QK 型およびダイク型に、まず大きさの異なる 3 種類の 落石を、順次落下させた。つづいて、土砂を落下させた。 斜面は直高で約 15〜20mあり、勾配は約 8 分（約 $51^{\circ}$ ) である。各実験ケースの条件を表-2に示す。

表一2. 実験条件一覧表

\begin{tabular}{|l|l|l|l|l|}
\hline & 1投目 & 2投目 & \multicolumn{1}{|c|}{ 3投目 } & 4投目 \\
\hline & 落石 & 落石 & 落石 & 土砂 \\
\hline QK型 & 約0.2t & 約1.0t & 約2.0t & 約12.0m3 \\
\hline ダイク型 & 約0.25t & 約1.0t & 約2.6t & 約12.0m3 \\
\hline
\end{tabular}

\section{4 . 実験内容}

（1）実験盛土構築

a)ダイク型

ダイク型の構築フローを図-9に示す。

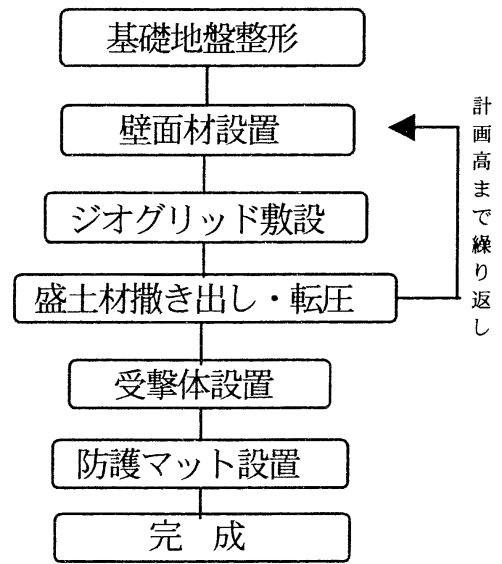

図-9.ダイク型構築フロー図

ダイク型の構筑概要は以下の通りである。各段階での 施工状況を写真-1〜 3に示す。

(1) 基礎地盤を計画高さに整形して不陸をとる。

(2) 壁面材を並べ外枠を作る。壁面材には施工場所の現 状に合わせ植生シートもしくはのり面保護シートを 設置する。

(3) ロール状になったジオグリッドを構造物の延長方向 
に敷設する。

(4) 盛土材を敷き均し転圧する。のり先部分の土が入り にくいところは手作業で入れ込み、空隙ができない よう考慮する。

(2)〜4)までを計画高さまで繰り返す。

(5) 受撃体の設置を行なう。受撃体は設置位置で中詰材 の充填を行なう。袋にたるみがでないように充填す る。

（6) 受撃体前面に受撃体保護用のシートを設置する。熱 風溶着器によりシートを繋げながら設置する。

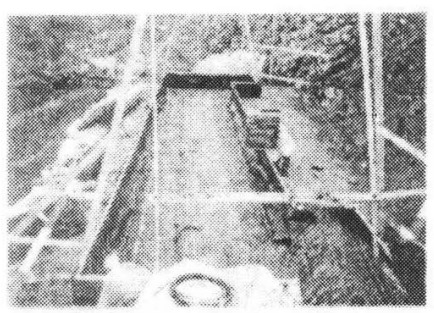

写真-1 . (2) (3)完了

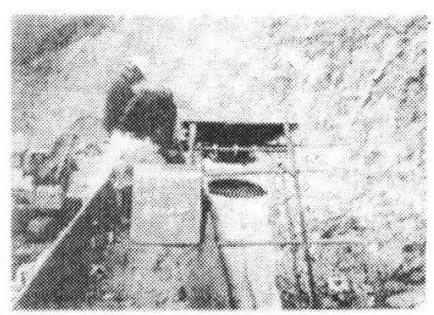

写真- 2. (5)施工状況

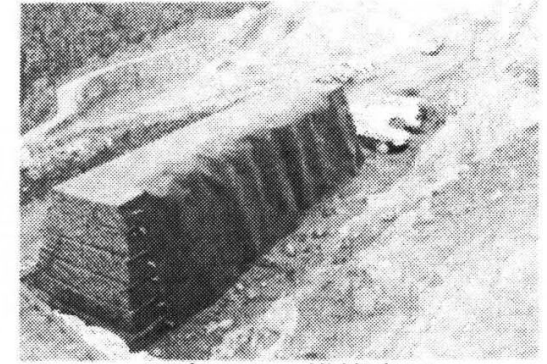

写真 -3 . 構築完了

b) QK型

QK型の施工フローを図-10に示す。

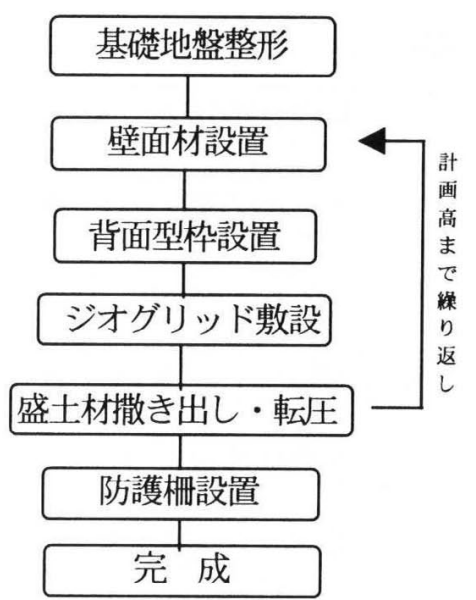

QK型

図-10.0K 型構築フロ一図

(1) 基礎地盤の整形及び背面切土を行なう。

(2) 壁面材を並べ外枠を作る。壁面材には施工場所の現 状に合わせ植生シートもしくはのり面保護シートを 設置する。

(3) 地山側に背面型枠を設置する。

(4) ジオグリッドを敷設長十巻き込み長 $1.0 \mathrm{~m}$ でカット して地山と鈶直方向に敷設する。ジオグリッドの巻
き込み部は撒き出し時には背面側に折り返しておく。

(5) 盛土材を敷き均し転圧する。のり先部分の土が入り にくいところは手作業で入れ込み空隙ができないよ う考虑する。

(2)〜(5)までを計画高さまで繰り返す。

(6) 防護柵の設置を行なう。根入れ部分は先導管を盛土 構築時に埋設しておきその中に支柱を建てこむ。

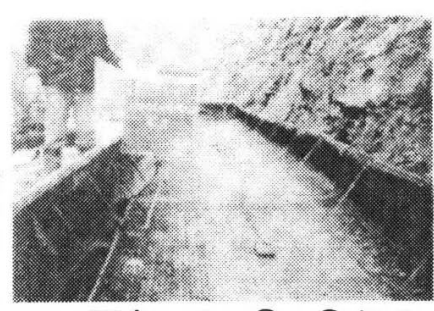

写真-4 . (2)〜 (4)完了

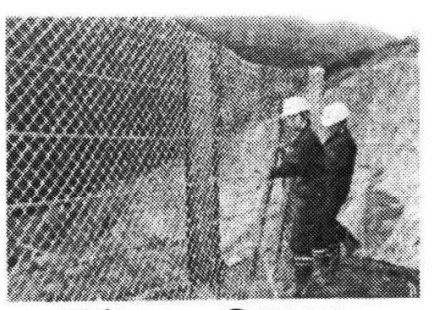

写真- 5. (6)設置状況

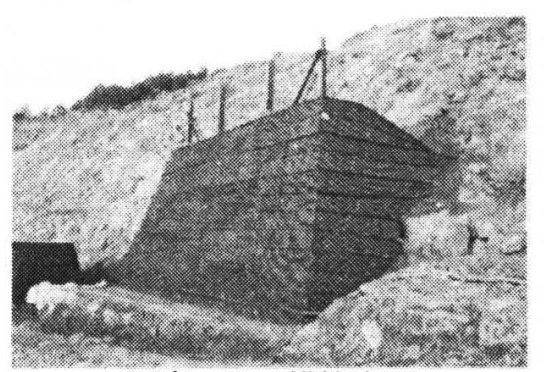

写真 -6. 構築完了

（2）実験実施

実験の流れを図-11に示す。

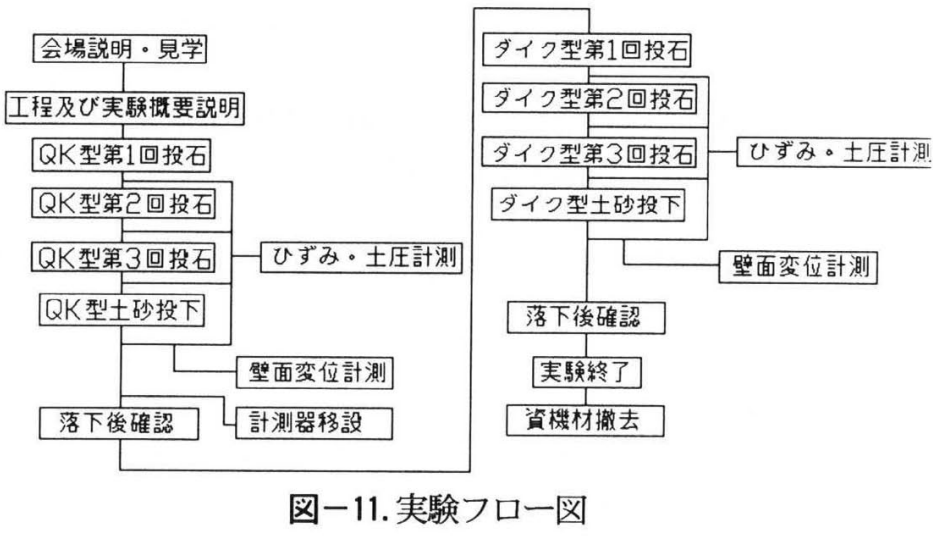

本実験は図-12 のように高さ $20.0 \mathrm{~m}$ 前後で公配 $1: 0.8$ 程度の斜面下部にダイク型および $\mathrm{QK}$ 型を並べ, 斜面上 部から建設重機を使用してQK 型〜ダイク型の順番で計 測ケースに示した条件で落下させた。

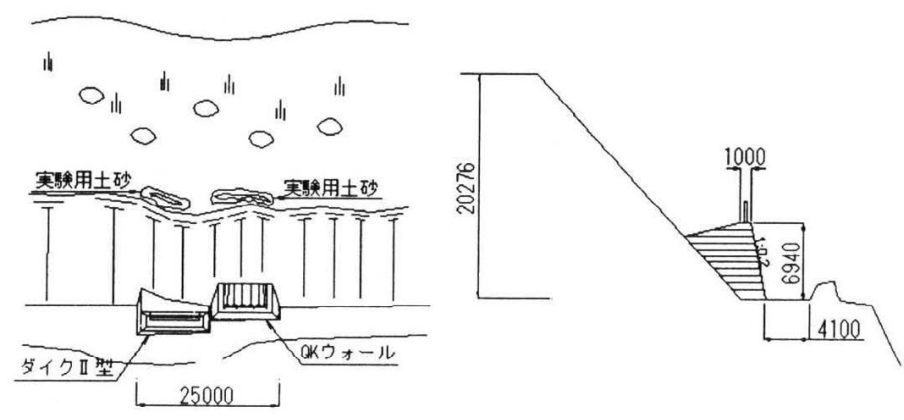

図-12. 構築斜面状況図 


\section{5. 実験結果}

ここでは結果の一例として、土砂落下時と、最も大きな 落石の結果のみを示す。QK 型に配置したひずみゲージ の結果を図-15 に、土圧計の結果を図-16 に示す。落石 衝突時と土砂衝突時の結果を示す。図中の計測器の位置 は図-8に示す。また、落石の衝突位置及び土砂の堆積 状況を図-13・14に示す。

実験の結果、落石・土砂の衝突時に、ひずみの増加はほ とんど見られない。土圧計の值は、土砂が堆積するにつ れて増加している。しかし、落石時には、土圧に変化は 見られない。今回の落石の規模は最大で $300 \mathrm{~kJ}$ の落石工 ネルギーが想定されるが、今回の QK 型の規模で変化が 見られる落石エネルギーには程遠いものだったと考える。 過去にこの規模の実験を行なった時は、盛土に変化が見 られる落石エネルギ一は 1000kJ 以上であった ${ }^{5)}$ 。また、 土砂落下時についても、落下前と落下後の壁面変位は最 大で $1 \mathrm{~mm}$ 程度であった。つまり、この規模の落石と土砂 に対してQK 型は、十分に安定しているといえる。

同様にダイク型に配置したひずタゲージの結果を図-17 に、土圧計の結果を図-18 に示す。土砂落下時には、ひ ずみゲージには変化は見られないが、土圧計に土砂が堆 積した分の変化が見られる。ひずみゲージに変化が見ら れなかったことは、今回の土砂荷重に対して、補強土提 体が全く影響を受けずに擁壁として内的安定を十分に維 持していると考える。落石時は、ひずみゲージに変化が 見られる。落石が衝突した瞬間、落石エネルギーによる 提体の変形に抵抗する形で引張 $(+)$ 側にひずみが発生し ている。その後、変形の大きな個所(落石の衝突箇所)ほ ぞ、大きな残留ひずみが生じている。また、今回の落石 は入射角が比較的急角度であったため、土圧計に大きな 変化が見られる。衝突の瞬間に $100 \mathrm{kPa}$ 近くの土圧が発 生し、その後落石の重量分の残留が見られる。しかし、 ひずみの絶対量は小さく、壁面変位は最大で $3 \mathrm{~mm}$ 程度の 結果であり、衝撃荷重が背面の筒型土のうと提体内で、 十分に吸収されていることが分かる。ダイク型において も、今回の規模の落石と土砂に対して, 十分に安定して いることがわかる。

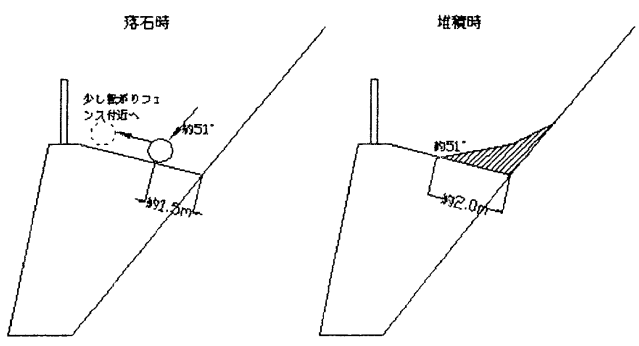

図-13.QK 型落石時および堆砂時状況
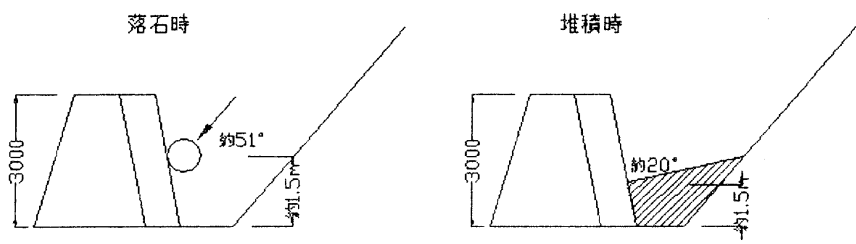

図-14.ダイク型落石時および堆砂時状況

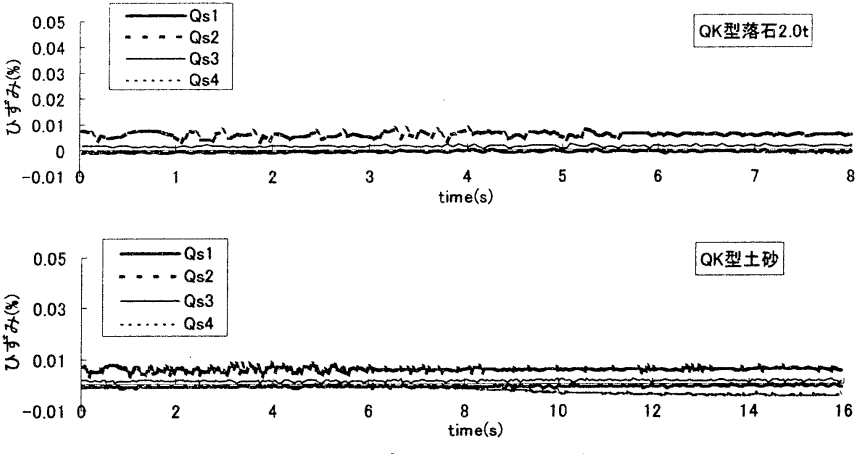

図-15 ひずみ計測結果（QK型）
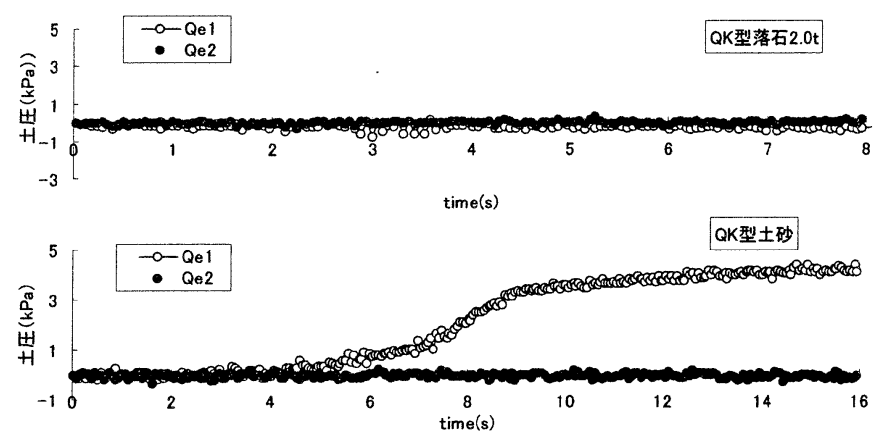

図-16 土圧計測結果（QK 型）
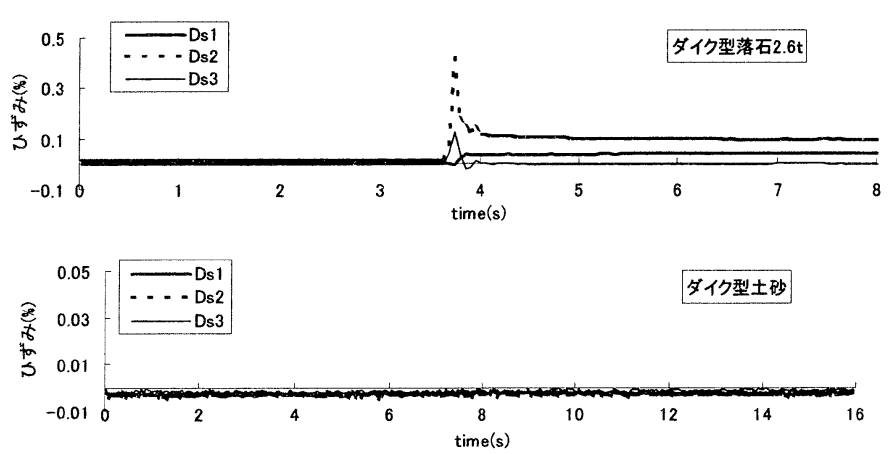

図-17 ひずみ計測結果（ダイク型）

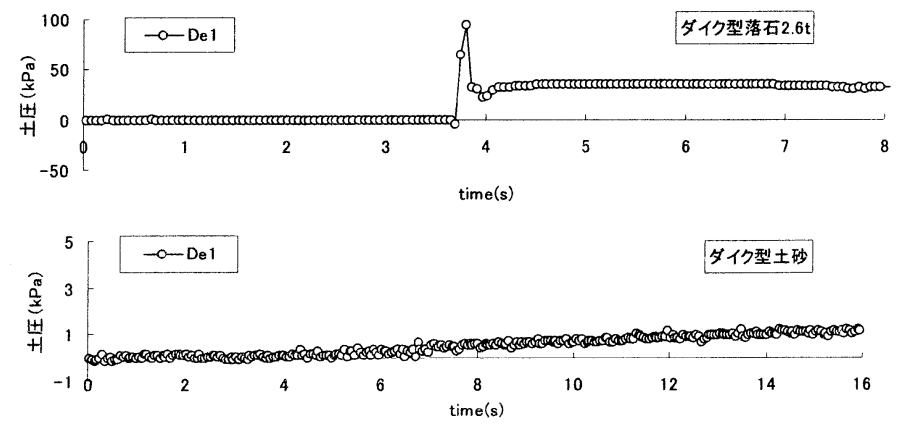

図-18 土圧計測結果（ダイク型）

\section{5. 考察}

今回の計測結果により以下のことがいえる。

(1)今回の規模の衝撃ではほとんど変位がなく，十分適用 可能と考えられる。

(2)壁面変位および内部応力から推定すると，限界值まで 
十分な余裕があり，大きな斜面災害にまで効果がある と考えられる。

(3)ダイク型の落石衝突時に土圧計が反応しているが，壁 面の計測結果より転倒モードなどの外的挙動は無いた め土粒子の移動により土圧計が圧迫されたと考えられ る。

\section{6. 今後の課題}

本実験は性能確認に加え，公開実験というデモ的な要 素もあったため, 細部の検証まで行かなかった。今後は これらの実績を踏まえモデル実験などを実施し，さらな る性能の信頼性を確立してゆきたい。

謝辞 : 今回の確認試験を実施するにあたり文部科学省科 学技術技術振興調整費（研究課題：環境共生型補 強土河川護岸工法の開発一代表 八嶋厚) の援助 を受けた。ここに記して深謝の意を表す。また実 験フィールドの提供に尽力いただいた（財）岐皁 県建設研究センター広瀬氏および日鳥鉱山俐の皆 様にもこの場を借りて深謝の意を表す。
参考文献

1）永吉他：落石防護補強土擁壁のモデル衝撃実験結果 の分析（その 1)，第 37 回地盤工学研究会発表会講演 集 pp. 2267-pp. 2268, 2002 年

2）井上他 : 落石防護補強土壁のモデル衝突実験結果の 分析 (その 2),第 37 回地盤工学研究発表会講演集, pp. 2255-pp. 2256, 2002 年

3）土砂災害防止法令の解説，（社）全国治水砂防協会発 行

4）松岡他：「土のう」の力学特性および而圧試験,第 35 回地盤工学研究会発表講演集 pp. 1075-pp. 1076, 2001 年

5）㴊上他（2000）：ジオシンセティックスを用いた落 石防護擁壁の実験的研究,ジオシンセティックス論文 集第 15 巻 pp. $350-$ pp. 359,2000 年

\title{
FullscaleFieldtest of Reinforced Enbankment adjacent to SteepSiope
}

\section{Masaki YOSHIDA $^{1)} \cdot$ Naoki TATSUTA $^{2)} \cdot$ Youichi NISHIDA $^{3)} \cdot$ Syouichi INOUE $^{4)} \cdot$ Atsushi YASHIMA $^{\text {) }}$}

\author{
Kazuhide SAWADA ${ }^{\text {9) }} \cdot$ Syuji MORIGUCHI ${ }^{7}$ •
}

The reinforced embankments using geotextile have been utilized as rock fall defense. The reinforced embankment absorbs shock load of rock fall and has high strength so that it can apply wide rock falling energy such as 100 to 5000kJ. In the construction of this structure, it can use turned soil taken place at the field so that it can cut costs. Assume slope failure on steep slope, and we demonstrate the high durability of reinforced embankment by applying shock load to two types of full size models. This paper reports the structural characteristic and construction technique of reinforced embankment. 